DOI https://doi.org/10.18551/rjoas.2018-01.01

\title{
EXTERNAL MOBILITY OF THE POPULATION OF MONTENEGRO: OVERVIEW
}

\author{
Bulatović Jelisavka* \\ College of Textile Design, Technology and Management, Belgrade, Serbia \\ Rajović Goran* \\ International Network Center for Fundamental and Applied Research, Russia \\ *E-mail: jelisavka.bulatovic@gmail.com
}

\begin{abstract}
Spatial mobility of population is one of the basic demographic determinants. Montenegro is characterized not only by internal migration, but also by external resettlement of population. An uncontrolled migration lead to the demographic polarization of the country is to widening of the emigration areas and narrowing if the immigration ones. So, Montenegro made a stride towards a new millennium with a polarized spatial distribution of population.
\end{abstract}

\section{KEW WORDS}

Montenegro, region, population, external migration.

Along with births and deaths, migration is one of the three demographic components of population change, and has often been described as the most difficult to measure, analyze, and predict. It is estimated that $3 \%$ of the world's population are external migrants, the United States being the country with the largest number of immigrants. In other regions, such as Asia, Latin America and Africa, the rate of emigration exceeds that of immigration, while in North America, Europe and Oceania, there is the opposite effect, that is, the percentage of immigrants exceeds that of migrants. The three largest flows of external migration are from Asia to Europe, from Asia to North America and from Latin America to North America. The global pattern reflects the importance of migration from less developed countries to more developed countries. Migrants from countries with relatively low incomes and a high rate of growth tend to move towards slightly richer countries where employment prospects are slightly more favorable. According to recent statistics, more than 20 million people have become in recent years forced immigrants, i.e. refugees, due to international and interregional conflicts, civil wars, natural difficulties, hunger and poverty.

Many studies deal with international migration - Montenegro (Penev, 2008; Rajović, 2011; Vukčević, 2016; Zlatičanin, 2016) as it is becoming an increasingly important component of population change (Freeman et al, 2013; Lowell, 2013; Predojević - Despić and Penev, 2014). External migration is a complex, percussive and dynamic phenomenon, therefore this text is not able to respond to all social, economic and cultural issues that arise. In that sense, text she tries to offer, from a geographical perspective, some answers and explanations of the phenomenon of "external migration" in Montenegro, in the more precise way in which it was possible to comprehend it, to get to know mentioned issues. So, this paper points to the main determinants of external mobility of the population of Montenegro.

\section{MATERIALS AND METHODS OF RESEARCH}

Some basic methodological principles for a critical geography of migration include interdisciplinary and comparative studies that can increase awareness of general trends and alternative approaches. According to Singleton (1999) the subject matter of international migration is cross - national in scope, whilst international migration statistics are the products of national government ministries, administrations and statistical institutes. The counting tools used to measure the phenomena associated with the movement of people across borders are limited, conceptually, linguistically and within the legal definitions applied by each 
national jurisdiction. This creates constraint in the area of cross - national policy development as well as a challenge to researchers attempting to measure an $d$ analyze patterns of migration across Europe an d between EU member states an d other counter (Borkert et al, 2006; De Beer et al,2010; Robertson, 2015; Boese and Marotta, 2017). The whole information volume in this article was obtained through specific methods for the selective research, respecting all its stages from the methodological point of view: identification of the researched issue, research framework delimitation, information collection, data processing, analysis and interpretation drawing up the conclusions. Research also played an important role in the article, which consisted, on one hand, in the identification of other studies and articles on the same subject, and in the processing of some statistic data, on the other hand. Hence, the information sources used can be classified into governmental sources (statistic, ministerial and from research institutes), and into non - governmental sources (independent publications) (Abel, 2010; Raymer et al, 2011; Raymer et al, 2013; Rajović, 2017; Rajović and Bulatović, 2017).

\section{RESULTS AND DISCUSSION}

Throughout the 20th century Montenegro has been a typical emigration area. Prior to 1990, the first major wave of emigration launched immediately after World War II, was directed to Serbia... In the period between 1953 and 1961 the net migration rate was negative $(-7.2 \%)$. The second major wave of migration from Montenegro occurred in the 1965 - 1973 period. It was a massive emigration abroad, jointly organized by the Federal State Agency of the SFRY and the main migration receiving countries (Germany, Austria, France, and Switzerland) in the frame of guest-worker agreements (MMWD - Making Migration Work for Development).

According to the estimates provided by the Government of Montenegro, the number of expatriates and migrants from Montenegro worldwide is about 200.000, which is consistent with the estimated size of the Montenegrin Diaspora as estimated by the IOM, This number, would be larger if it would take into account Montenegrins by ancestry. Though the exact number of Montenegrin immigrants and their descendants around the world is unknown, the Ministry of Foreign Affairs estimated that their number is equal to the number of people currently living in Montenegro. Following Ministry of Foreign Affairs Montenegrin immigrants and their descendants live mostly in North and Latin America, Serbia, Turkey, Western Europe and countries of the former Yugoslavia, but a significant number of them live in Australia, Russia and some African countries (MMWD - Making Migration Work for Development).

Table 1 - Montenegrin Citizens Abroad by the Country of Residence (Census 2003)

\begin{tabular}{|c|c|c|}
\hline United States & 18.700 & $35,0 \%$ \\
\hline Germany & 11.344 & $21,2 \%$ \\
\hline Switzerland & 11.344 & $5,3 \%$ \\
\hline Luxembourg & 2.722 & $5,1 \%$ \\
\hline Sweden & 2.279 & $4,3 \%$ \\
\hline France & 1.288 & $2,4 \%$ \\
\hline Netherlands & 1.202 & $2,2 \%$ \\
\hline Denmark & 1.202 & $2,2 \%$ \\
\hline Italy & 1.198 & $2,2 \%$ \\
\hline Other European Countries & 6.194 & $11,6 \%$ \\
\hline Australia & 1.024 & $1,9 \%$ \\
\hline Other non- European Countries & 1.270 & $2,4 \%$ \\
\hline Unknown & 2.200 & $4,1 \%$ \\
\hline Total & 53.433 & $100,0 \%$ \\
\hline
\end{tabular}

Source: Statistical Office of Montenegro - Monstat (2008).

According to the data of the Statistical Office of Montenegro (2012) the number of citizens of Montenegro in abroad, or stay in the country in 2003 (Table 1) was: United States (18.700), Germany (11.344), Switzerland (11.344), Luxembourg (2.722), Sweden (2.279), 
France (1.288), Netherlands (1.202), Denmark (1.202), Italy (1.198), Other European Countries (6.194), Australia (1.024), Other non- European Countries (1.270) and Unknown (2.200). According to the Euro barometer survey, conducted between March and May 2008, with the statement that "immigration greatly contributes to their country", agreed $44 \%$ of the citizens of the European Union, a disagreement was expressed by $47 \%(9 \%$ of the respondents did not know). However, a new wave of research in 2012, pointed to the positive change in the attitudes of citizens.

The same argument was supported by $49 \%$ of the population, an increase of 5 percentage points, and reduced the number of citizens that immigration negatively rate to $43 \%$ (the percentage of those who do not know the answers to that question has remained virtually the same $8 \%$ ). The greatest differences were observed at the national level. While this stance supporting citizens of the old EU member states $(89 \%$ in Sweden, $77 \%$ in Luxembourg and $66 \%$ in Portugal, and to a lesser proportion of the citizens of Denmark, Holland, Finland, Great Britain, Ireland, Germany, Spain and France), among residents of the new Member States this claim is much less widespread: $17 \%$ support in Estonia, $18 \%$ in the Czech Republic and $21 \%$ in Slovakia, Latvia and Cyprus (the Values of Europeans - Report 2012) (Poleti, 2013).

According to Nikitović (2009) migration is a phenomenon that is the most difficult to predict, especially in countries like Montenegro. There are several reasons for this, and they can be classified into two main groups. The first relates to the poor quality of data on external migration, and the other on a strong political and economic conditionality of migration flows. Namely, official data does not cover all the immigrants from Montenegro; thanks to the people who are leaving the country usually do not report a change of residence. Indirect conclusions on their number can be performed based on the data of countries receptor, but this applies only to persons who are registered (Rajović and Bulatović, 2017). "Today, the state administration of the immigration countries is under constant pressure because they have to balance between the opening and closing of borders" (Nowaczek, 2010).

In the series of factors according to Medar and Chirtoc (2012) can be identified in the decision mobility (Figure 1) include: economic and political causes, establishing mobility networks, previous experience of mobility, the need for professional development through continuing education in a county that provides higher education opportunities the county of origin and family reunification.

This interesting and an extremely research Medar and Chirtoc (2012) indicates that "Mobility phenomenon has existed since the beginning of mankind. Phenomenon has not stopped in time, but has changed and acquired new forms. The balance between population and resource changes by the emergence of a surplus population, representing a "emigration zone" or the occurrence of surplus resources, representing a "immigration zone". Mobility is one of the ways in which regions can adjust to economic change and a way that ensures growth. Mobility flows can act as an "automatic stabilizer" for the region, giving people the opportunity to improve their standard of living by moving to areas with conditions of employment and better living. The spatial balance of supply and labor demand often involves relocation, being involved the other family members (some inactive), in this case, the labor mobility being with implications not only by economical nature, but also by social and demographic nature. Is not to be neglected the role of migrants in increasing urbanization ratio of a region, and economic growth, the increase mobility is the main cause of population growth to city and urban population in general". In Montenegro, the development of economic life, changes occurred in the economic development process restructuring operated in the national economy caused population mobility from one region to another, mainly from economic reasons (Zhou, 2001; Jackson et al, 2001; Alba et al, 2002; Rosemberg et al, 2016).

According to Portes and Böröcz (1989) "the upper left cell on Figure 2 deceptions the common situation wish has given rise to most stereotypes about contemporary immigration. Manual labor migrants arriving in contexts in which their kind are unwelcomed or discriminated against tend to be channeled toward the lower tier of the receiving labor market. 


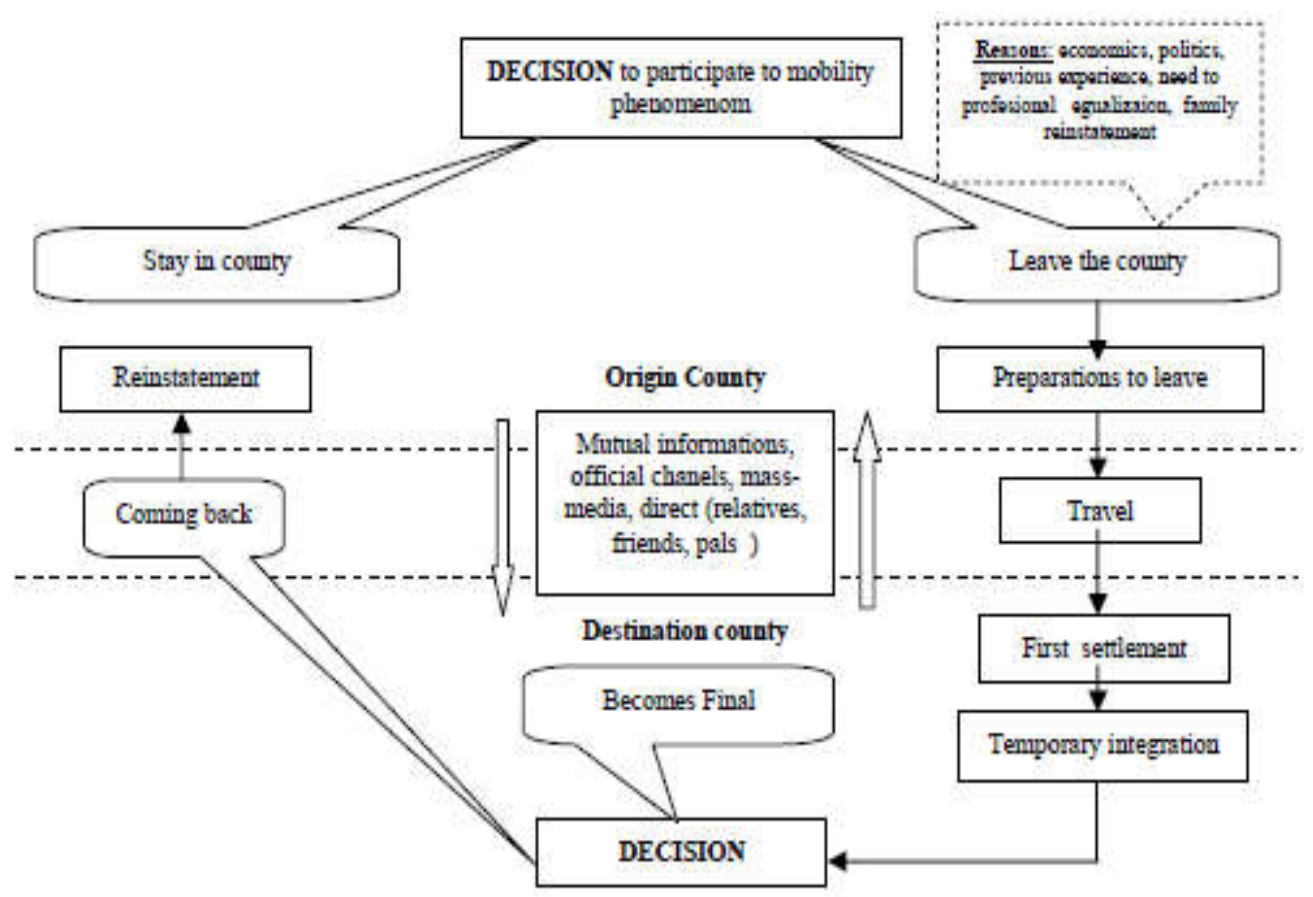

Figure 1 - Decision and mobility reasons (Medar and Chirtoc, 2012 according to Blaga and Moştenescu, 2008)

\begin{tabular}{|c|c|c|c|}
\hline \multirow[t]{2}{*}{$\begin{array}{l}\text { CONTEXT OF } \\
\text { RECEPTION }\end{array}$} & \multicolumn{3}{|c|}{$\begin{array}{l}\text { CLASS OF } \\
\text { ORIGIN }\end{array}$} \\
\hline & Manual Labor & $\begin{array}{l}\text { Professional- } \\
\text { Technical }\end{array}$ & Entrepreneuri \\
\hline IANDICAPPED & $\begin{array}{c}\text { Secondary } \\
\text { Market } \\
\text { Incorporation }\end{array}$ & $\begin{array}{l}\text { Ghetto Service } \\
\text { Providers }\end{array}$ & $\begin{array}{l}\text { Middleman } \\
\text { Minorities }\end{array}$ \\
\hline NEUTRAL & $\begin{array}{l}\text { Mixed Labor } \\
\text { Market } \\
\text { Participation }\end{array}$ & $\begin{array}{l}\text { Primary Market } \\
\text { Incorporation }\end{array}$ & $\begin{array}{c}\text { Mainstream } \\
\text { Small Busines }\end{array}$ \\
\hline ADVANTAGED & $\begin{array}{c}\text { Upward } \\
\text { Mobility to } \\
\text { Small } \\
\text { Entrepreneurship }\end{array}$ & $\begin{array}{c}\text { Upward } \\
\text { Mobility to } \\
\text { Positions of } \\
\text { Professional and } \\
\text { Civic Leadership }\end{array}$ & $\begin{array}{l}\text { Enclave } \\
\text { Economies }\end{array}$ \\
\hline
\end{tabular}

Figure 2 - A tipology of modes of incorporation of contemporary immigrants to the advanced countries (Portes and Böröcz, 1989)

Characteristic of this secondary sector have been the subject of some controversy, but there is growing Conesus among scholars that is it defined by jobs which require little or no prior training, which cluster at the low end of the wage scale, which offer little or no mobility opportunities, and which are subject to rapid employee turnover" (Kritz et al, 1994; Elie et al, 2011; Piché, 2013; Kumar et al, 2014).

\section{CONCLUSION}

Our research records are based on similar research Mikačić (2000) indicates that spatial mobility of population is one of the basic demographic determinants. Regarding 
migration, Montenegro is a dynamic country, which is characterized not only by internal migration, but also by external resettlement of population. An uncontrolled migration lead to the demographic polarization of the country is to widening of the emigration areas and narrowing if the immigration ones. So Montenegro made a stride towards a new millennium with a polarized spatial distribution of population (Rajović and Bulatović, 2016).

According to Analytical Study of Montenegrin Diaspora, a recent internal report from the Montenegrin Diaspora Administration notes the relevance of incorporating this population into the country's development: "Taking advantage of globalization trends and rationally laid out diplomatic networks, a foundation should be made for engaging competent members of Montenegrin Diaspora which would be in mutual interest for the country and its citizens abroad" (Bekteši, 2012). Managing this (human and intellectual) potential is an essential condition for further progress and development of Montenegro.

From the analysis of European external policies on migration according to Palm (2016) emerges a picture which can be summarized with four key concepts: externalization of migration control, conditionality in relations with third countries, focus on securitization of borders and absence of legal routes for asylum seekers. All these policies have undoubtedly negatively impacted the international protection guarantees. In 2016, this status quo has partially been challenged: the conclusion of a broad agreement with a third state on migration cooperation seems at first sight a positive step forward, even if, when looked at more closely, the latter reveals to be mainly a reflection of the abovementioned key concepts.

The recent New Partnership Framework nevertheless appears to have the potential to challenge the current setting: it aims on the one hand to create a single framework for agreements with third states to enhance coordination and avoid segmentation and, on the other hand, to take a more multi-focal viewpoint representing also the interests of third states. But in order for it to be so, the EU's solidarity impasse, demonstrated both by the lack of agreement on relocation and the absence of any discourse on opening regular access channels, needs to be overcome - but at present it sadly looks like the EU will continue on its path of turning to third countries in order to distract from its internal divisions (Palm, 2016).

The EU has developed its Global Approach to Migration as a possible way to establish comprehensive cooperation with non-EU partners from the East and the South on a whole range of migration issues, including the fight against irregular migration, legal migration, migration and development, and asylum policy. The approach also had a coordinating effect for internal EU policy-making. There have been, however, four main challenges hampering this policy domain: 1) the limited ability of the EU to define its migration policy with its 27 sovereign States; 2) tensions between the national and supranational level in the EU as regards international cooperation on migration; 3 ) the diverging interests and priorities of sending regions and/or partner countries; 4) the limited implementation capacities of the EU and its Member States, as well as of partner countries (Weinar, 2011),

\section{REFERENCES}

1. External Migration: Reasons, Factors and Consequences (2017), Available from: http://www.lifepersona.com (05. 11 2017).

2. Penev, G. (2008). Demographic trends in Montenegro from the mid 20 century and perspectives up to 2050. Podgorica: Statistical Office of Montenegro.

3. Rajović, G. (2011). Montenegrin immigrants in Denmark. Belgrade: Copyright edition, Agency PC System.

4. Vukčević, M. (2016). Causes and characteristics of the Montenegrin emigration. Available from: htpp//www.dijasporacg.me (04.11 2017).

5. Zlatičanin, B. (2016). Montenegrins in Albania, Mainstream: Journal of Social Issues, Science and Culture. Cetinje; Podgorica: Mainstream Montenegrin.

6. Freeman, G. P. (2013). Pointless: On the failure to adopt an immigration points system in the United States. In Wanted and Welcome? (pp. 123 - 143). Springer New York.

7. Lowell, B. L. (2013). Skilled Immigration Policy in the United States: Does Policy Admit "Enough" Skilled Workers?. In Wanted and Welcome? (pp. 105 - 121). Springer NY. 
8. Predojević - Despić, J., Penev, G. (2014). Emigration zones in Serbia: 2011 census results. Zbornik Matice srpske za drustvene nauke. Vol. 148, pp. 383 - 397.

9. Singleton, A. (1999). Combining quantitative and qualitative research methods in the study of international migration. International Journal of Social Research Methodology. Vol. 2, No. 2, pp. 151 - 157.

10. Borkert, M., Pérez, A. M., Scott, S., De Tona, C. (2006). Introduction: Understanding migration research (across national and academic boundaries) in Europe. In Forum Qualitative Sozialforschung/Forum: Qualitative Social Research (Vol. 7, No. 3).

11. De Beer, J. (2010), .Overcoming the problems of inconsistent international migration data: A new method applied to flows in Europe. European Journal of Population/Revue européenne de Démographie. Vol. 26, No. 4, pp. 459 - 481.

12. Robertson, S. (2015). The temporalities of international migration: implications for ethnographic research, In Social Transformation and Migration (pp. 45 - 60). UK.

13. Boese, M. (Eds.) (2017). Critical Reflections on Migration, 'Race' and Multiculturalism: Australia in a Global Context. Taylor \& Francis.

14. Abel, G. J. (2010). Estimation of international migration flow tables in Europe. Journal of the Royal Statistical Society: Series A. Vol.173, No. 4, pp. 797 - 825.

15. Raymer, J. (2011). Putting the pieces of the puzzle together: Age and sex-specific estimates of migration amongst countries in the EU/EFTA, $2002-2007$. European Journal of Population/Revue européenne de Démographie. Vol. 27, No. 2, pp. 185 - 215.

16. Raymer, J. (2013). Integrated modeling of European migration. Journal of the American Statistical Association. Vol. 108, No. 503, pp. 801 - 819.

17. Rajović,G. (2017). Migrants from the former Yugoslavia to Denmark in the context of the time: historical aspects, Gaidar's Readings 2017, vol. 1

18. Rajović, G., Bulatović,J. (2017). Cultural Identity and Language of Children of Migrants from Serbia and Montenegro who live in Denmark - Preliminary Research Report. European Journal of Social and Human Sciences. Vol. 4, No. 2, pp. 79 - 87.

19. MMWD - Making Migration Work for Development. Country Perspective, Migration profile/Montenegro/. Available from: http://www.southeast-europe.net (03.11 2017).

20. Statistical Office of Montenegro - Monstat (2008). Census in Montenegro in 2003. Podgorica: Statistical Office of Montenegro.

21. Statistical Office of Montenegro - Monstat (2012). Census of Population, Households and Dwellings in Montenegro 2011. Podgorica: Announcement number 83.

22. Poleti, D. (2013). Contemporary Labour Migration in European Context - Economic and Political Aspects. Sociologija. Vol LV, No 2, pp. 333 - 348.

23. Nikitović, V. (2009). Serbia as a country of immigration - the expected future. Stanovništvo. Vol. 1, pp. $31-52$.

24. Rajović, G., Bulatović,J. (2017). Mobility of Population in Montenegro; Traffic in Northeast Montenegro. Scholars' Press, Saarbrucken, Germany.

25. Nowaczek, K. (2010). Pressure of migration on social protection systems in the enlarged EU. In: Engbersen, Godfried; Okólski, Marek; Black, Richard; Panţîru, Cristina (ed.), A Continent Moving West? EU enlargement and labour migration from Central and Eastern Europe. IMISCOE Research. Amsterdam: University Press.

26. Medar, L. I. (2012). Analyse of Labor Force Mobility Phenomenom on Romanian Internal Market. Of the University of Petrosani - Economics. Vol. 12, No.1, pp. 193 - 204.

27. Blaga, E., Moştenescu, R. (2008). Labor force migration. Bucharest: University of Bucharest Publishing House.

28. Portes, A. (1989). Contemporary immigration: Theoretical perspectives on its determinants and modes of incorporation. Int. Migr. Review. vol.23, No.3, pp. 606-630.

29. Kritz, M. M., Nogle, J. M. (1994). Nativity concentration and internal migration among the foreign - born. Demography. Vol. 31, No. 3, pp. 509 - 524.

30. Elie, J., Lieber, M., Lutringer, C. (2011). Migration et développement: les politiques de la Chine et de l'Inde à l'égard de leurs communautés d'outre-mer. Vol. 2, No. 2, pp. 215 230. Institut de hautes études internationales et du développement. 
31. Piché, V. (2013). Contemporary migration theories as reflected in their founding texts. Population. Vol. 68, No. 1, pp. 141 - 164.

32. Kumar, P., Bhattacharya, U., Nayek, J. K. (2014). Return migration and development: Evidence from India's skilled professionals. In Indian Skilled Migration and Development (pp. 263 - 284). Springer India.

33. Zhou, M. (2001). Contemporary immigration and the dynamics of race and ethnicity. America becoming: Racial trends and their consequences. Vol. 1, pp. 200 - 242.

34. Jackson, J. S., Brown, K. T., Brown, T. N., Marks, B. (2001). Contemporary immigration policy orientations among dominant-group members in Western Europe. Journal of Social Issues. Vol. 57, No. 3, pp. 431 - 456.

35. Alba, R., Logan, J., Lutz, A., Stults, B. (2002). Only English by the third generation? Loss and preservation of the mother tongue among the grandchildren of contemporary immigrants. Demography. Vol. 39, No. 3, pp. 467 - 484.

36. Rosemberg, M. A. S., Boutain, D. M., Mohammed, S. A. (2016). Transnationalism: A Framework for Advancing Nursing Research with Contemporary Immigrants. ANS, Advances in nursing science. Vol. 39, No. 1, E 19.

37. Mikačić, V. (2000). Spatial Mobility of the Population of Croatia - Internal Migration. Hrvatski geografski glasnik. Vol. 62, No. 1, pp. 1 - 21.

38. Rajović, G., Bulatović,J. (2016 a). Review on Demographic Changes in the Agricultural Population of Montenegro, the Structure of Agricultural Land and Economic Development. vol. 4, pp.181 - 188.

39. Rajović, G., Bulatović, J. (2016 b). Regional Aspects of the Population in Montenegro: Review. Population Processes. Vol. 1, No. 1, pp. 27 - 34.

40. Rajović, G., Bulatović, J. (2016 c). Demographic Changes in the Population of Northern Region in Montenegro with Emphasis on Enterpreneurship: a Review. Asian Journal of Social and Human Sciences. Vol. 1, No. 1, pp. 19 - 27.

41. Rajović, G., Bulatović, J. (2016 d). Demographic processes and trends: the case of northeastern Montenegro. Russian Journal of Agricultural and Socio - Economic Sciences. Vol. 3, No. 51, pp. 14 - 29.

42. Rajović, G., Bulatović, J. (2016 e). Regional Inequalities Population of Montenegro with Overview of Regional Indicators. Population Processes. Vol. 2, No. 2, pp. 37 - 45.

43. Rajović, G., Bulatović, J. (2016 f). Some Demographic Changes in the Population of Montenegro with the Projection of Future Demographic Development. Journal of Advocacy, Research and Education. Vol. 5, No. 1, pp. 23 - 28.

44. Analytical Study of Montenegrin Diaspora. Available from: http://www.ukf.hr (02.11 2017).

45. Bekteši, E. (2012). "Statistical data on emigrations from Montenegro in the 2nd half of the 20th century". Diaspora Administration internal report. Ministry of Foreign Affairs, Montenegro.

46. Palm, A. (2016). Did 2016 Mark a New Start for EU External Migration Policy, or Was It Business as Usual?. Istituto Afari Internazionali, pp. 1-18.

47. Weinar, A. (2011). EU cooperation challenges in external migration policy. Research Report Background paper EU-US Immigration Systems 2011/02. 